\title{
Apologetika Prasuposisional Triperspektivalisme John M. Frame dan Aplikasinya terhadap Pemikiran Kristen Pluralis tentang Pluralisme Agama di Indonesia
}

\author{
Andry Setiawan* \\ *Rohaniwan yang telah menyelesaikan program Sarjana Teologi (2006) dan Magister Teologi di STT-SAAT \\ (2017). Pada saat ini sedang melayani di Gereja Kristus Yesus (GKY) Jemaat Bumi Serpong Damai (BSD), \\ Serpong, Tang-Sel. \\ Email: andry_setiawan_kuang@yahoo.com
}

\begin{abstract}
Abstrak: Pluralisme menjadi kesadaran baru yang menganggap bahwa semua keyakinan memiliki kesamaan secara umum satu dengan yang lain. Implikasinya, tidak ada satu pun agama yang boleh mengklaim bahwa ia adalah satu-satunya keyakinan yang paling benar di antara agamaagama lainnya. Indonesia sebagai negara pluralis juga menghadapi problematika pluralisme agama. Dalam menghadapi ini, muncul pemikiran Kristen pluralis yang menekankan persamaan di antara agama-agama sehingga meniadakan keunikan kekristenan: Kristus dan karya keselamatan-Nya benar sedangkan agama lainnya salah. Tulisan ini akan mengenalkan model berapologetika yang membela keunikan iman Kristen di tengah tantangan pemikiran Kristen yang pluralis tentang pluralisme agama di Indonesia: apologetika prasuposisional triperspektivalisme John M. Frame yang diuraikan melalui apologetika konstruktif (normatif), defensif (eksistensial), dan ofensif (situasional).
\end{abstract}

Kata-kata kunci: Apologetika, Prasuposisional, Triperspektivalisme, John M. Frame, Aplikasi, Pluralisme Agama

\begin{abstract}
Pluralism exhibits a new awareness that assumes that all beliefs have general similarity when compared one with another. As a result, there is no religion that can claim that it has the claim to ultimate truth when compared with a host of other options. Indonesia, as a pluralistic nation, exhibits the challenges of religious pluralism. Because of that reality, there are frameworks of Christian thought that have arisen that emphasize the similarity of several religions which erodes and ultimately eliminates the uniqueness of Christianity. However, Jesus Christ and his work of salvation is absolutely true and the other religions are false. This article will introduce an apologetic model that can be used to defend the uniqueness of the Christian faith among the challenges of religious pluralistic thought in Indonesia. John M. Frame's triperspectivalism presuppositional apologetics is proferred and developed through constructive apologetics (normative), defensive apologetics (existential), and offensive apologetics (situational).
\end{abstract}

Keywords: Apologetics, Presuppositional, Triperspectivalism, John M. Frame, Application, Religious Pluralism 


\section{Pendahuluan}

Salah satu fakta yang tidak dapat disangkali oleh semua orang pada era milenium ketiga adalah dunia yang semakin pluralistis dalam budaya, bahasa, wawasan dunia (worldview), moralitas, seni, dan agama. Keadaan ini kemudian berkembang menjadi sebuah cara pikir atau filosofi yang disebut pluralisme. Perkembangan pola pikir ini ditegaskan oleh

Veli-Matti Kärkkäinen sebagai tantangan yang harus dihadapi dengan serius oleh kekristenan pada permulaan milenium ketiga karena paham ini secara garis besar (rough) menganggap agama-agama di dunia-termasuk kekristenan-memiliki kesamaan dan tidak memiliki otoritas final. ${ }^{1}$

Sebagai negara yang pluralistis, Indonesia juga mengalami "serangan" dari pluralisme. Menurut Williem Ferdinandus, hal ini bukan hanya disebabkan keragaman yang kompleks seperti suku, bahasa, budaya, agama melainkan juga karena sikap ekstrem dari para teolog dan praktisi Kristen. ${ }^{2}$ Kaum pluralis

\footnotetext{
${ }^{1}$ Trinity and Religious Pluralism: The Doctrine of the Trinity in Christian Theology of Religions (Aldershot: Ashgate, 2008), 2. Lihat juga Daniel B. Clendenin, Many Gods, Many Lords: Christianity Encounters World Religions (Grand Rapids: Baker, 1995), 11-18.
}

${ }^{2}$ Lihat "Trinity and Religious Pluralism: Peran Doktrin Trinitas dalam Pluralitas Agama," Amanat Agung 9, no. 2 (Desember 2013): 206. Sikap menekankan persamaan di antara agama-agama di Indonesia lebih banyak diprakarsai dan diikuti oleh gereja-gereja Indonesia yang berlatar belakang ekumenis seperti gereja Katolik Roma (19621963) sebagai tindak lanjut dari Konsili Vatikan II dan juga kelompok gereja arus utama (mainline churches). Gereja-gereja arus utama beranggotakan sebagian tokoh-tokoh Persekutuan Gereja-gereja di Indonesia (PGI) dan Dewan Gereja-gereja Sedunia (DGD). Tokoh-tokoh yang terlibat di dalamnya adalah J.B. Banawiratma (pengajar teologi di Yogyakarta), Franz Magnis-Suseno, dan Muji Sutrisno di mana keduanya adalah pengajar di Sekolah Tinggi Filsafat Driyarkara Jakarta, Eka Dharmaputera, Olaf Schuman, Ioanes Rakhmat (awal) yang notabene berlatar belakang STT Jakarta pada saat itu. Selain itu, Emanuel Gerrit Singgih dari STT Duta Wacana Yogyakarta, Th. Sumartana, dan John A. Titaley dari Satya Wacana (UKSW) Salatiga serta Weinata Sairin dari Persekutuan Gereja-gereja di Indonesia (PGI). Penjelasan lebih lanjut dapat dilihat Harianto GP, "Gagasan Pluralisme Agama: Tinjauan Sejarah dari Indonesia sampai Kini dan Tawaran Dialog 'Kebenaran Agaphe'," Pelita Zaman 16, no. 1 (Mei 2001): 33-47. mengutamakan sikap mencari dan menekankan kesamaan Kristen dan agama-agama lain sehingga tidak jarang meniadakan keunikannya. Sikap ini kemudian menjadi sebuah tantangan bagi kaum Injili mempertahankan keunikannya. ${ }^{3}$ Pada umumnya, kaum Injili mengambil posisi sebagai eksklusivis atau partikularis yang meyakini bahwa di luar Kristus Yesus tidak ada jalan keselamatan yang lain. ${ }^{4}$ Dalam konteks ini, maka penulis berusaha mengenalkan sebuah pendekatan apologetika Injili yang disebut: apologetika prasuposisional perspektivalisme yang digagas oleh John M. Frame. Penulis juga akan mencoba menerapkan model apologetika ini untuk menyoal berbagai prasuposisi pemikiran Kristen pluralis tentang pluralisme agama di Indonesia. Argumentasi penulis adalah bahwa model apologetika tersebut dapat mempertanggungjawabkan keunikan iman Kristen di tengah konteks pluralisme agama. Hal ini didasarkan pada beberapa pertimbangan, yaitu: Pertama, apologetika prasuposisional triperspektivalisme dan pemikiran Kristen pluralis berangkat dari prasuposisi yang berbeda. Sebab itu, masing-masing memiliki kesempatan untuk menjelaskan pandangannya tanpa saling merendahkan pandangan satu dengan yang lain. Kedua, prasuposisi Kristen dapat menyingkapkan "kebodohan"

${ }^{3}$ Pengertian Injili mengacu kepada definisi Injili (evangelikal) berdasarkan John M. Frame: "Seseorang yang mengakui teologi Protestan historis. Hal ini mencakup kepercayaan-kepercayaan berikut: Allah, manusia, Yesus Kristus, keselamatan, Kitab Suci, dan doa." Lihat "Introduksi pada Iman Reformed," Veritas 8, no. 2 (Oktober 2007): 173. Lebih lanjut, Chandra Wim memberikan penjelasan spesifik tentang evangelikalisme sebagai gerakan yang bersumber dari gereja mula-mula di abad pertama di mana tidak memandang dirinya sebagai kreasi baru yang muncul di dalam perkembangan sejarah kekristenan, melainkan sebagai Kristen ortodoks yang setia mengimani iman para rasul. Namun, Wim menjelaskan bahwa menurut pakar kekristenan, evangelikalisme baru muncul dalam sejarah kekristenan sekitar abad ke-18 yang didahului dengan tiga gerakan historis, yaitu gerakan Reformasi, Puritanisme, dan Pietisme. Untuk penjelasan lebih lanjut, lihat "The Cronicles of Evangelicalism: Sebuah Pengantar Historis terhadap Gerakan Evangelikal," Veritas 12, no. 2 (Oktober 2011): 185-207.

${ }^{4}$ Daniel L. Lukito, "Eksklusivisme, Inklusivisme, Pluralisme, dan Dialog Antar-Agama," Veritas 13, no. 2 (Oktober 2012): 259. 
kaum pluralis Kristen dengan mengontraskan kedua prasuposisi sehingga diharapkan terjadi perubahan prasuposisi dari kaum Kristen pluralis. Ketiga, apologetika prasuposisional triperspektivalisme senantiasa mencari tahu dengan jelas konteks pemikiran Kristen pluralis sehingga dapat menjadi jembatan (point of contact) antara kedua prasuposisi itu yang mencakup wahyu umum dan kebenaran parsial yang telah diputarbalikkan dan ditekan sedemikian rupa oleh kaum Kristen pluralis.

\section{Apologetika Prasuposisional Triperspektivalisme John M. Frame}

Apologetika prasuposisional atau prasuposisionalisme pada umumnya digunakan oleh kaum Reformed. John M. Frame menyebut metode apologetika tersebut sebagai aksi untuk memprasuposisikan kebenaran firman Tuhan. ${ }^{5}$ Kegiatan ini membuktikan kepada seseorang bahwa jika ia percaya kepada Allah maka ia pasti akan menjadikan Wahyu-Nya sebagai kebenaran yang tertinggi di dalam totalitas kehidupannya. Jika tidak demikian, hal itu disebut dosa. Dengan demikian, pendekatan ini menegaskan bahwa argumenargumen apologetika tidak dapat "netral" dan harus memilih antara otoritas Allah dan firman-Nya atau yang lain. Jika seorang percaya ingin memuliakan Tuhan maka tentu saja ia sudah semestinya menempatkan Allah dan firman-Nya di atas segala-galanya.

Salah satu tokoh yang memakai pendekatan tersebut adalah John M. Frame (1939-). Frame dikenal sebagai salah satu apologet prasuposisional dan penerus dari pemikiran Van Til. William Edgar dan K. Scott Oliphint menyebut Frame sebagai "apologet masa kini yang pandai mengemukakan pikirannya dan produktif dalam tradisi prasuposisionalis Reformed." ${ }^{\prime}$ Sebutan ini didasarkan pada kemampuan Frame untuk meneruskan, menggunakan, mengkritisi, dan mengembangkan

\footnotetext{
${ }^{5}$ Apologetics to the Glory of God: An Introduction (Phillipsburg: P\&R, 1994), 9.

${ }^{6}$ Christian Apologetics Past and Present: A Primary Source Reader: From 1500 (Wheaton: Crossway, 2011), 2:721.
}

pendekatan prasuposisional yang tidak dilakukan oleh Van Til sebelumnya berlandaskan pada epistemologi Reformed, yaitu teori perspektivalisme atau triperspektivalisme. ${ }^{7}$ Teori ini menjelaskan kesatuan di dalam keberagaman perspektif, yaitu normatif, situasional, dan eksistensial. Sebelum metode apologetika prasuposisional triperspektivalisme ${ }^{8}$ dibahas lebih dalam, diperlukan pembahasan terlebih dahulu mengenai epistemologi alkitabiah dari apologetika tersebut.

\section{Epistemologi Alkitabiah}

Epistemologi dari APT dimulai dari prasuposisi. Kata ini dapat dipahami sebagai " $a$ belief that takes precedence over another and therefore serves as a criterion for another. An ultimate presupposition is a belief over which no other takes precedence." 9 Dengan kata lain, prasuposisi merupakan keyakinan dan komitmen yang paling mendasar dari seseorang. Karena itu, prasuposisi menjadi kriteria tertinggi atas kebenaran dan standar untuk menerima atau menolak sebuah gagasan.

Bagi orang Kristen, Alkitab sebagai wahyu khusus sudah tentu menjadi prasuposisi tertinggi. Ia menjadi sumber dan standar kebenaran bagi orang percaya. Hal ini ditegaskan oleh Frame, "Scripture actually has a great deal to say about epistemology, or theory of knowledge." ${ }^{10}$ Alkitab mengajar tentang bagaimana seseorang dapat memperoleh pengetahuan (hikmat), yaitu dimulai dari takut akan Tuhan. ${ }^{11}$ Sikap yang "takut" kepada

\footnotetext{
${ }^{7}$ Cornelius Van Til: An Analysis of His Thought (Phillipsburg: P\&R, 1995), 1-18.

${ }^{8}$ Untuk selanjutnya disingkat menjadi APT.

${ }^{9}$ John M. Frame, The Doctrine of the Knowledge of God (Phillipsburg: P\&R, 1987), 45.

10"Presuppositional Apologetics," dalam Five Views on Apologetics, ed. Steven B. Cowan (Grand Rapids: Zondervan, 2000), 208.

${ }^{11}$ John M. Frame menyatakan, "In the view of Scripture, the most important kind of knowledge is the knowledge of God. Knowing God is the key to all other knowledge: 'The fear of the Lord is the beginning of knowledge' (Prov. 1:7). So knowledge is fundamentally knowledge of a person. It is also covenantal, since the personal God is our covenant
} 
Tuhan menunjuk kepada hati yang hormat, kagum, dan taat kepada-Nya. Hal ini dapat terjadi karena didasarkan pada pengenalan Allah sebagai Tuhan, tuan di dalam kehidupan. Gagasan ini yang kemudian disebut oleh Frame sebagai konsep ketuhanan (lordship). Gagasan ini akan diuraikan menjadi tiga bagian, yaitu objek pengetahuan, justifikasi pengetahuan, dan metode pengetahuan.

\section{Objek Pengetahuan}

Konsep ketuhanan yang ilahi dan alkitabiah merupakan titik awal untuk mengenal Allah sebagai objek pengetahuan. Pemikiran ini memiliki tiga poin penting, yaitu ketuhanan dan kovenan, transendensi dan imanensi, serta kontrol, otoritas, dan kehadiran. Ketuhanan yang ilahi dan alkitabiah adalah sebuah konsep kovenan. Allah adalah kepala dari kovenan dan hidup dengan menaklukkan segala pikiran, hati merupakan wujud dari ucapan syukur atas anugerah yang Ia berikan kepada manusia. ${ }^{12}$

Kemudian, transendensi dan imanensi. Frame menulis, "If God is covenant head, then He exalted above His people; He is transcendent. If He is covenant head, then He is deeply involved with them; He is immanent."13 Transendensi menjelaskan bahwa Allah berbeda dari ciptaan-Nya karena Ia adalah Pencipta dan tidak diciptakan sedangkan ciptaan diciptakan oleh Dia. Imanensi menunjuk kepada Allah yang tidak pernah meninggalkan buatan tanganNya. Jadi, Allah sebagai kepala kovenan adalah pribadi yang senantiasa berelasi dengan ciptaan-Nya.

Lord. He calls upon us to seek knowledge as his obedient servants" (The Doctrine of God [Phillipsburg: P\&R, 2002], 480). Pernyataan Frame menunjukkan dengan jelas relasi yang erat antara pengetahuan tentang Allah dengan konsep ketuhanan di dalam kehidupan orang percaya.

\footnotetext{
${ }^{12}$ Allah mengomunikasikan diri-Nya kepada ciptaan-Nya sebagai Tuhan yang mengikat perjanjian (kovenan) dengan umat-Nya (Lihat John M. Frame, The Doctrine of the Word of God [Phillipsburg: P\&R, 2010], 10-11).
}

${ }^{13}$ The Doctrine of the Knowledge of God, 13. Lihat juga John M. Frame, The Doctrine of God, 103-115.
Selanjutnya, kontrol, otoritas, dan kehadiran. Allah kovenan yang transenden dan imanen menjelaskan atribut (sifat dasar) Allah. Transenden merujuk kepada kontrol dan otoritas Allah sedangkan imanensi menunjuk kepada kehadiran Allah. Allah sebagai Pencipta berbeda dengan ciptaan-Nya sehingga Ia memiliki kontrol dan berdaulat atas mereka. 14 Sedangkan otoritas menunjukkan bahwa Allah adalah pribadi yang berkuasa di dalam seluruh kehidupan manusia, tanpa terkecuali. ${ }^{15}$ Imanensi Allah merujuk kepada kehadiran Allah yang mengekspresikan kedekatan Allah dengan ciptaan-Nya dan terlibat aktif di dalam kelangsungan hidup mereka. Setiap ciptaan mengalami kehadiran Allah secara nyata karena Ia adalah Tuhan yang personal. Menurut Frame, "Allah yang imanen adalah pribadi yang mau terlibat dan hadir bersama dengan ciptaan-Nya." 16

Mengenal Allah tidak hanya melalui wahyu khusus (Alkitab/Hukum) tetapi juga wahyu umum. Wahyu umum memiliki signifikansi yang penting sama seperti wahyu khusus. Hal ini dikarenakan dua wahyu tersebut merupakan pemberian Allah untuk memperkenalkan Allah kepada ciptaan-Nya. Wahyu umum ini mencakup dunia dan manusia yang merupakan media ciptaan di mana Allah menyatakan hukum-hukum-Nya. Frame berpendapat bahwa hukum Allah adalah diri-Nya sendiri sedangkan Allah sendiri adalah hukum bagi ciptaan-Nya. Hukum ini juga dinyatakan kepada kita melalui beberapa media, yaitu alam, sejarah, hati nurani, teofani, nubuat, dan Alkitab. Semua media tersebut samasama menyatakan Allah sebagai sumber hukum. ${ }^{17}$ Dengan demikian, mengenal Allah sudah semestinya melibatkan tiga objek

\footnotetext{
${ }^{14}$ Lihat penjelasan lebih lanjut Ibid., 15-16. Lihat juga Frame, The Doctrine of God, 36-79; John M. Frame, The Doctrine of the Christian Life (Phillipsburg: P\&R, 2008), 21-22.

${ }^{15}$ Lihat ibid., 16. Lihat juga Frame, The Doctrine of God, 80-93; Frame, The Doctrine of the Christian Life, 22-23.

${ }^{16}$ Ibid., 17. Lihat juga Frame, The Doctrine of God, 94-102; Frame, The Doctrine of the Christian Life, 23-24.

${ }^{17}$ Lihat ibid., 63.
} 
pengenalan, yaitu hukum-Nya, dunia, dan diri manusia itu sendiri.

Meskipun berbeda, ketiganya saling berhubungan. Keadaan ini menunjukkan bahwa pemahaman orang percaya mengenai hukum akan sama dengan pemahamannya terhadap situasi dunia dan dirinya sendiri sebagai ciptaan Allah. Ketiga unsur tersebut merupakan perspektif satu terhadap yang lain dan secara keseluruhan (whole). Kemudian, ia menyebut perspektif itu sebagai triperspektivalisme yang terdiri dari perspektif normatif (hukum), situational (dunia), dan eksistensial (manusia) $^{.18}$

\section{Justifikasi Pengetahuan}

Ketika seorang Kristen mengenal tentang Allah melalui hukum-Nya, dunia, dan diri sendiri maka tiba saatnya ia harus berpikir apa yang menjadi dasar untuk menyatakan bahwa pengetahuannya tersebut benar atau tidak. Ini yang disebut sebagai justifikasi pengetahuan. Meskipun berfokus pada perspektif normatif (hukum Allah), justifikasi pengetahuan itu tetap harus memperhatikan "fungsi normatif" dari ketiga perspektif. Sebab itu, seperti objek pengetahuan, justifikasi pengetahuan juga melibatkan tiga perspektif, yaitu normatif (hukum Allah), situasional (dunia), dan eksistensial (diri). ${ }^{19}$ Jadi, tiga perspektif ini senantiasa berelasi erat satu sama lain untuk menjelaskan mengenai justifikasi pengetahuan.

\section{Metode Pengetahuan}

Perspektif eksistensial dari pengetahuan membahas tentang bagaimana manusia memperoleh pengetahuan yang ia cari. Meskipun demikian, perspektif normatif dan situasional tetap dilibatkan di dalam metode pengetahuan ini. Pertama, perspektif normatif akan membahas mengenai penggunaan Alkitab.

${ }^{18}$ Lihat ibid., 73. Lihat juga John M. Frame, "The Spirit and the Scripture," dalam Hermeneutics, Authority, and Canon, ed. D.A. Carson dan John D. Woodbridge (Grand Rapids: Zondervan, 1986), 230. 108.

${ }^{19}$ Lihat Frame, The Doctrine of the Knowledge of God,
Hal ini tentunya berhubungan dengan hermeneutika (ilmu penafsiran) dan diwujudkan di dalam teologi yang mencakup teologi eksegesis, teologi biblika, teologi sistematik, dan teologi praktika. Cabang-cabang teologi ini berbeda satu dengan yang lain dalam penekanan, fokus dan cara penyusunan materinya tetapi mengungkapkan hal yang sama, yaitu penggunaan Alkitab. ${ }^{20}$

Kedua, perspektif situasional. Perspektif ini akan membahas tentang penggunaan faktafakta di luar Alkitab dan alat-alat seperti sains untuk menemukan fakta tersebut. Konkretnya, teologi menggunakan berbagai macam data di luar Kitab Suci (extrabiblical). Frame menegaskan bahwa teologi bukan saja mengulangi bahasa Alkitab tetapi juga mengaplikasikan dan merelasikan bahasa tersebut kepada situasi dunia yang kita tinggali. ${ }^{21}$ Data-data di luar Alkitab yang relevan dengan teologi berasal dari berbagai sumber seperti bahasa, logika, sejarah, ilmu pengetahuan, dan filsafat. Semua ilmu ini disebut sebagai alat teologi yang berfungsi untuk menganalisis datadata tersebut.

Ketiga, perspektif eksistensial. Perspektif ini akan membahas kapasitas, keterampilan, dan kemampuan seorang percaya, dan sikapsikap yang relevan dengan ilmu pengetahuan. Pengetahuan tentang Allah adalah pengetahuan hati. Hati adalah "pusat" kepribadian dari manusia sendiri dalam sifatnya yang paling mendasar. Frame menerangkan, "Scripture represents it [heart] as the source of thought, of volition, of attitude, of speech. It is also the seat of moral knowledge."22 Implikasi dari pernyataan ini adalah pengetahuan orang percaya tentang Allah berkaitan erat dengan kesalehan karakternya. Seorang yang berteologi bukan hanya memiliki pengetahuan dan terampil menggunakan alat-alat teologi, melainkan juga hati yang takluk kepada kebenaran Alkitab.

\footnotetext{
${ }^{20}$ Lihat ibid., 206-214.

${ }^{21}$ Ibid., 215.

${ }^{22}$ Ibid., 322.
} 
Berdasarkan pemaparan mengenai konsep ketuhanan beserta dengan objek pengetahuan, justifikasi pengetahuan, dan metode pengetahuan yang berelasi secara perspektival, maka dapat dipahami bahwa pengetahuan manusia akan Allah berlandaskan pada Alkitab. Prasuposisi yang dimiliki orang Kristen, yaitu Alkitab adalah standar dan sumber dari pengetahuan kita akan Allah. ${ }^{23}$ Hal tersebut dipahami dari tiga perspektif di mana masing-masing memiliki penekanan yang berbeda-beda. Namun, perlu dipahami bahwa perspektif normatif dan Kitab Suci itu sendiri adalah dua hal yang berbeda. Frame menjelaskan bahwa perspektif normatif bukan Alkitab melainkan pemahaman seseorang atas Alkitab yang berelasi dengan dirinya dan ciptaan. Melalui perspektif normatif, seseorang menguji seluruh pengetahuannya dengan fokus pada Alkitab serta memandang semua pengetahuan itu sebagai "aplikasi dari Alkitab."24 Jadi, Kitab Suci adalah firman Allah dan satu-satunya standar dan sumber kebenaran yang mutlak bagi setiap orang percaya sedangkan Kitab Suci sebagai perspektif normatif merupakan pemahaman yang tentunya mengandung interpretasi atas Kitab Suci yang harus ditopang dengan perspektif situasional (fakta) dan perspektif eksistensial (diri).

\section{Apologetika Prasuposisional Triperspektivalisme}

Berdasarkan epistemologi alkitabiah di atas, maka Frame menggambarkan APT sebagai metode apologetika yang memakai tiga perspektif dalam argumen sirkular secara luas untuk membenarkan pendiriannya, menggunakan Alkitab, alat-alat di luar Alkitab, dan segenap karunia apologet sendiri berupa karakter yang saleh dan kecakapan yang terampil. ${ }^{25}$ Tiga perspektif tersebut mencakup perspektif normatif, situasional, dan eksistensial yang berakar teguh dalam komitmen pada ketuhanan Kristus. Prasuposisi demikian memiliki poin yang paling fundamental, yaitu

\footnotetext{
${ }^{23}$ Lihat Frame, Apologetics to the Glory of God, 9

${ }^{24}$ Frame, The Doctrine of the Knowledge of God, 163.

${ }^{25}$ Ibid., 348.
}

"aplikasi dari sola scriptura kepada apologetika."26 Dengan demikian, setiap argumen apologetika yang dipakai oleh orang percaya, bahkan seluruh aspek kehidupannya akan memprasuposisikan ketuhanan Kristus Yesus dan kebenaran firman Tuhan.

\section{Elemen-elemen APT}

APT memiliki tiga elemen penting, yaitu menunjukkan (proof), membela (defense), dan penyingkapan (offense). Jika dilihat secara perspektival maka APT memiliki perspektif normatif (menunjukkan), situational (pembelaan), dan eksistensial (penyingkapan). ${ }^{27}$ Pertama, menunjukkan. Elemen ini adalah sebuah usaha untuk menyampaikan sebuah dasar rasional bagi iman Kristen. Dengan usaha ini, iman Kristen ditunjukkan oleh apologet sebagai keyakinan yang benar. Hal ini dilakukan bukan hanya bagi orang tidak percaya tetapi juga kepada orang percaya. Hal ini disebabkan orang-orang percaya terkadang dapat mengalami keraguan (doubt). Oleh karena itu, diperlukan penyingkapan berdasarkan Kitab Suci baik bagi keraguan orang percaya maupun ketidakpercayaan (unbelief) orang tidak percaya.

Kedua, pembelaan adalah kegiatan untuk menjawab keberatan-keberatan yang bersumber dari ketidakpercayaan. Kitab Suci mencatat bahwa Paulus melakukan pembelaan atas Injil Kristus (Flp. 1:7). Pola ini juga berlaku di dalam surat-surat Paulus lainnya. Yesus Kristus pun melakukan hal yang serupa di mana Ia berhadapan dengan sejumlah keberatan yang diajukan oleh para pemimpin agama Yahudi (Yoh. 3; 5, 6:25-59; 7:14-52; 8; dst.).

\footnotetext{
${ }^{26}$ Frame, "Presuppositional Apologetics," 363. Pada intinya, APT Frame mengkritisi tiga epistemologi tradisional seperti rasionalisme, empirisme, dan subjektivisme di mana "correspond to the three non-Reformed approaches to apologetics: fideism tends to subjectivism, evidentialism is based on some form of empiricism, and classical apologetics tends to rationalism" (Kenneth D. Boa dan Robert M. Bowman, Jr., Faith has Its Reasons: Integrative Approaches to Defending the Christian Faith, ed ke-2 [Colorado Springs: Paternoster, 2006], 473).
}

${ }^{27}$ Apologetics to the Glory of God, 2-3. 
Ketiga, penyingkapan adalah tindakan untuk menyerang atau membukakan kebodohan dari pemikiran yang tidak percaya (Mzm. 14:1; 1Kor. 1:18-2:16). Seorang apologet bukan hanya menjawab setiap keberatan yang diajukan oleh orang yang tidak percaya melainkan juga "menyerang" kebodohannya. Hal ini sesuai dengan Kitab Suci (1Kor. 3:18-23) sehingga salah satu fungsi apologetika adalah untuk menyingkapkan kebodohan tersebut yang terwujud di dalam dialektika rasionalis-irasionalis.

Ketiga elemen ini selaras dengan definisi Frame mengenai apologetika, yaitu "Sebuah aplikasi Kitab Suci kepada orang yang tidak percaya." 28 Melalui tiga elemen itu, diharapkan orang yang tidak percaya dapat memercayai Tuhan dan taat sepenuhnya kepada Kitab Suci. Pada akhirnya, ia akan meyakini bahwa wahyu Allah bukan hanya benar melainkan juga adalah kriteria tertinggi dari kebenaran, kepastian yang paling fundamental, dan dasar bagi seluruh pemikiran yang dapat dipahami dan hidup yang berarti. ${ }^{29}$ Ketiga elemen tersebut tentu saja berhubungan erat satu sama lain. Ketika salah satu unsur dikerjakan dengan baik dan tepat maka akan mencakup jenis lainnya. Teknisnya, Frame menerangkan bahwa untuk memberikan penjelasan penuh mengenai keyakinan yang rasional (proof), maka seseorang harus mempertahankan pemikiran rasional itu terhadap sejumlah keberatan (defense) dan memberikan alternatif-alternatif (offense) yang dinyatakan oleh orang-orang tidak percaya." ${ }^{30}$ Dengan demikian, tiga aspek ini saling melengkapi, menguatkan, dan tidak dapat dipisahkan satu dengan yang lain.

\section{Strategi APT}

Strategi untuk mengaplikasikan APT dapat dilakukan dengan dua kategori umum, yaitu

${ }^{28}$ The Doctrine of the Knowledge of God, 87.

${ }^{29}$ Lihat John M. Frame, "Presuppositional Apologetics," dalam New Dictionary of Christian Apologetics, ed. W.C. Campbell-Jack, Gavin McGrath, dan C. Stephen Evans (Leicester: InterVarsity Academic, 2006), 578.

${ }^{30}$ Apologetics to the Glory of God, 3 . defensif dan ofensif. Apologetika defensif adalah "sebuah pembelaan atas iman kekristenan terhadap sejumlah keberatan dari orang yang tidak percaya." ${ }^{31}$ Orang tidak percaya mengajukan pertanyaan kepada orang percaya mengenai iman Kristen. Orang tersebut berinisiatif untuk mengajukan sanggahannya kepada orang percaya, kemudian orang percaya berespons dengan memberikan jawaban kepada dia.

Perspektif normatif dari apologetika defensif berfokus pada pengertian yang baik dari seorang apologet tentang Kitab Suci dan dapat menggunakannya secara tepat dan kreatif. Prasuposisi yang ditunjukkan adalah apologetika yang tunduk pada firman Allah yang dinyatakan-Nya. Selanjutnya, orang tidak percaya memiliki kesempatan untuk memakai reductio ad absurdum ${ }^{32}$ demi memperoleh ketidakjelasan (absurdities) dari premis kekristenan. Pihak kekristenan juga dapat meminta hal yang sama berdasarkan prasuposisinya masing-masing. ${ }^{33}$ Baik orang percaya maupun tidak percaya dapat menyatakan pandangannya berdasarkan prasuposisinya masing-masing.

Perspektif situasional menyatakan bahwa ada fakta-fakta di dalam dunia yang dapat digunakan untuk membela kekristenan. Fakta ini merupakan bukti-bukti (evidences) di luar Alkitab yang harus diinterpretasi secara alkitabiah. Menurut Frame, "An apologist has the obligation to underscore that evidence, to show the unbeliever "what to look for", as well as how to look for it and how to look at it. ${ }^{34}$ Pernyataan

\footnotetext{
${ }^{31}$ The Doctrine of the Knowledge of God, 348.
}

\footnotetext{
${ }^{32}$ Reductio ad absurdum adalah "the reduction of opposing position to absurdity" (ibid., 273). Hal ini merupakan salah satu jenis argumentasi deduktif yang mengasumsikan bahwa pandangan yang berlawanan dengan Alkitab benar "demi argumentasi." Berdasarkan hal itu, pandangan ini dijadikan premis dan disimpulkan apa yang tidak logis dari pandangan tersebut. Alhasil, premis itu dibuktikan salah. Bagi Frame, reductio ad absurdum bukan satu-satunya argumen yang cocok dengan ajaran Alkitab. Ia berpendapat, "I believe it is very useful" ("Presuppositional Apologetics," 223).
}

${ }^{33}$ Lihat The Doctrine of the Knowledge of God, 351.

${ }^{34}$ Ibid. 
ini menunjukkan bahwa setiap orang percaya harus menggunakan seluruh bukti secara alkitabiah kepada mereka yang belum percaya sekalipun bukti-bukti itu sudah mereka lihat pada wahyu umum. Seorang apologet sudah semestinya mengarahkan orang tidak percaya untuk memahami maksud Allah dengan memberikan semua bukti di luar Alkitab.

Perspektif eksistensial menerangkan bahwa ketika seorang percaya berapologetika, ia melakukannya untuk meyakinkan orang lain. Patut disadari bahwa tidak setiap argumentasi logis dapat menyakinkan setiap individu atau kelompok. Karena itu, ia harus menghadapi orang tidak percaya sebagai pribadi yang diciptakan segambar dan serupa dengan Allah, memahami kebutuhannya secara khusus serta mengembangkan argumentasi untuk menjawab kebutuhan tesebut. Roh Kudus yang mampu meyakinkan hati manusia di dalam kedaulatan-Nya tetapi usaha manusia pun beriringan dengan kedaulatan Allah. Hal ini ditegaskan oleh Frame: "God sovereignly acts through human agency, and human agencyhuman actions-are made effective because God is sovereign." 35

Di samping apologetika defensif, strategi APT dapat dilakukan pula dengan apologetika ofensif. Apologetika ofensif adalah "The Christian's own attack on unbelieving thought and life." ${ }^{36}$ Penyerangan yang dimaksud di sini adalah usaha untuk menyingkapkan kebenaran Allah kepada orang yang tidak percaya dan menaklukkan segenap pikirannya kepada Kristus (2Kor. 10:5). Frame menjadikan penyerangan sebagai langkah kedua dari apologetikanya setelah pertahanan dilakukan terhadap keberatan yang diajukan oleh orang tidak percaya. Penyerangan dilakukan terlebih dahulu dengan menyimak prasuposisiprasuposisi orang tidak percaya "demi kepentingan argumentasi" sehingga orang percaya dapat melakukan sebuah reductio, yaitu suatu demonstrasi bahwa premis-premis orang tidak percaya mengarah kepada ketidakjelasan

\footnotetext{
${ }^{35}$ Ibid., 354.

${ }^{36}$ Ibid., 348.
}

total. $^{37}$ Orang percaya mengatakan kepada orang tidak percaya tentang bagaimana pandangannya terhadap prinsip yang diyakini orang tidak percaya itu. Sama seperti apologetika defensif, apologetika ofensif juga harus dipandang dari tiga perspektif, yaitu normatif, situasional, dan eksistensial.

Perspektif normatif merujuk kepada pemahaman bahwa Kitab Suci mengajar orang percaya tentang iman dan akal sehat. Orang yang percaya dan tidak percaya sebenarnya sama-sama memiliki iman. Hanya yang menjadi masalah adalah iman orang tidak percaya didasarkan pada keyakinan yang buta sedangkan orang percaya beriman pada Tuhan yang diwahyukan dalam Kitab Suci." 38

Perspektif situasional memaparkan bahwa orang percaya dapat menyingkapkan kepada orang tidak percaya mengenai berbagai macam kesalahan seperti ketidakjelasan, kesalahan tentang fakta, dan kesalahan logika. ${ }^{39}$ Menurut Frame, ketidakjelasan terjadi karena kaum non-Kristen rasionalis dan irasionalis ${ }^{40}$ meminjam terminologi dan gagasan Kristen untuk mengungkapkan posisi mereka yang sangat menentang kekristenan. ${ }^{41}$ Kesalahan tentang fakta terjadi karena permasa-

${ }^{37}$ Ibid., 359.

${ }^{38}$ Ibid., 360.

${ }^{39}$ Logika adalah " $a$ way of understanding the meaning of texts. Logic is primarily concerned with (1) validity of arguments and (2) consistency of propositions" (John M. Frame, "Logic," dalam Dictionary for Theological Interpretation of the Bible, ed. Kevin J. Vanhoozer [Grand Rapids: Baker Academic, 2005], 462). Teks yang dimaksud adalah termasuk Alkitab.

${ }^{40}$ Istilah "rasionalis dan irasionalis" merujuk kepada dialektika dari struktur umum pemikiran orang tidak percaya. Hal ini dipergunakan oleh orang tidak percaya secara bersamaan untuk menggantikan kebenaran. Irasionalis adalah suatu pemikiran bahwa manusia kecil dan terbatas sehingga tidak dapat memahami Allah yang misterius dan jauh dengan benar. Ini adalah pandangan transendensi Allah ala orang tidak percaya. Sedangkan rasionalis adalah pemikiran yang menempatkan diri manusia sendiri di posisi Allah sebagai penentu tertinggi atas kebenaran dan kesalahan. Ini merupakan pandangan orang tidak percaya mengenai imanensi Allah (lihat The Doctrine of the Knowledge of God, 60).

${ }^{41}$ Ibid., 364. 
lahan hati orang tidak percaya yang membenci kebenaran dan menekan kebenaran itu. Kesalahan logika disebabkan ketidakpercayaan terhadap wahyu umum dan khusus.

Perspektif eksistensial merujuk kepada pengenalan orang percaya kepada lawan bicaranya baik secara individual maupun komunal. Hal ini dapat dilakukan secara dialog dan penuh kasih. Setelah itu, orang percaya selaku apologet memutuskan tentang bentuk penyampaian kebenaran firman Tuhan yang tepat bagi orang tidak percaya. ${ }^{42}$ Harapannya adalah berita Injil dapat disampaikan sejelas mungkin kepada orang tidak percaya. Pada akhirnya, dapat disimpulkan bahwa APT adalah sebuah metode apologetika yang mencoba mengaplikasikan Kitab Suci kepada orang tidak percaya dengan memprasuposisikan Kitab Suci sebagai sumber, standar, dan metode kebenaran melalui kegiatan menunjukkan apa yang Allah katakan di dalam Kitab Suci, membela iman kekristenan dari segala keberatan yang diajukan oleh orang tidak percaya, dan menyingkapkan segala ketidakpercayaan orang tidak percaya sehingga segenap pikiran dan kehidupannya ditawan dan ditaklukkan oleh Allah dan firman-Nya (2Kor. 10:5).

\section{Pemikiran Kristen Pluralis tentang Pluralisme Agama di Indonesia}

Pluralisme agama telah menjadi paham yang populer di dunia. Hal ini tentunya dilatarbelakangi dengan konteks dunia yang semakin hari semakin pluralistis. Keadaan tersebut juga terjadi di dalam kondisi bangsa Indonesia yang pluralistis di dalam segala hal termasuk agama. Karena itu, Indonesia tidak dapat menghindari pluralisme agama dan pengaruhnya bagi kekristenan di Indonesia.

\section{Perkembangan Gagasan Kristen tentang Pluralisme Agama di Indonesia}

Pluralitas agama di tanah air Indonesia berkembang menjadi sebuah pemikiran filosofis dan memandang bahwa semua agama di

\footnotetext{
${ }^{42}$ Lihat ibid., 367.
}

Indonesia secara umum memiliki kesamaan. Hal ini yang disebut sebagai pluralisme agama. Ideologi ini didahului dengan munculnya gerakan oikumene di Indonesia pada $25 \mathrm{Mei}$ 1950 melalui pembentukan Dewan Gerejagereja di Indonesia (DGI) yang berpusat di Jakarta. Tujuan semula pembentukan DGI adalah untuk menyatukan gereja-gereja di Indonesia tetapi kemudian pada tahun 1967 menjadi titik kritis bagi DGI untuk memiliki kesadaran akan pluralisme. Pergeseran ini didorong dengan kelahiran para teolog di Indonesia seperti Walter Bonar Sidjabat, Eka Darmaputera, Th. Sumartana, Ioanes Rakhmat $(\text { awal })^{43}$, dan John A. Titaley. ${ }^{44}$

W.A. Sidjabat memiliki ketertarikan untuk memikirkan toleransi agama. Ia berpendapat bahwa toleransi adalah ketabahan (endurance) atau kesediaan untuk masuk dan memperlakukan agama dengan penuh hormat dalam suatu dialog yang seakrab mungkin. Dialog yang dimaksud adalah "kesediaan untuk mendengar dari kedua belah pihak, namun tanpa jatuh ke dalam sinkretisme, skeptisisme dan relativisme." ${ }^{45}$ Hal ini yang selanjutnya disebut oleh Sidjabat sebagai toleransi agama

\footnotetext{
${ }^{43}$ Pandangan awal Ioanes Rakhmat semula tergolong di dalam kaum ekumenis yang pada akhirnya bergeser menjadi seorang pluralis. Namun dalam beberapa tahun terakhir, pemikirannya bergeser dan dinilai sebagai agnostik dan pemikir bebas (freethinker), bahkan bidat. Hal ini dibuktikan melalui bukunya sendiri yang berjudul "Membedah Soteriologi Salib: Sebuah Pergulatan Orang Dalam." Di dalam buku tersebut, Rakhmat menyatakan bahwa ia dengan bulat menolak ajaran keselamatan Kristen tentang kematian Yesus di atas kayu salib menebus orang dari dosa-dosanya dan menjamin orang yang percaya pada doktrin ini masuk surga (lihat Ioanes Rakhmat, Membedah Soteriologi Salib: Sebuah Pergulatan Orang Dalam, ed ke-2 [Jakarta: Borobudur, 2010], 12; Ioanes Rakhmat, "The Freethinker Blog: Album buku-buku saya My books album," The Freethinker Blog, August 6, 2012, diakses 2 Mei 2017, http://ioanesrakhmat.blogspot.co.id/2012/08/ album-buku-buku-saya.html.).

${ }^{44}$ Penulis hanya membahas pemikiran dari sejumlah teolog Indonesia yang di antaranya telah bergeser kepada pluralis dan sebagian secara terang-terangan mengambil posisi sebagai pluralis. Karena keterbatasan ruang, maka dalam artikel jurnal ini penulis tidak membahas pemikiran para pluralis kontemporer Indonesia seperti Joas Adiprasetya, Martin Sinaga, dan sebagainya.
}

${ }^{45}$ W.B. Sidjabat, Religious Tolerance and the Christian Faith (Jakarta: Gunung Mulia, 1965), 12. 
positif di mana di dalamnya terdapat kemerdekaan agama tanpa batas pada setiap agama sehingga orang Kristen tidak boleh memaksakan kehendaknya kepada orang lain. Sidjabat menulis: "Agar toleransi yang benar dapat terjadi hendaknya kita menghindari klaim bahwa kita mempunyai kebenaran. Ini berarti kita tidak bersaksi tentang superioritas agama Kristen terhadap agama-agama lain, tetapi bersaksi tentang Kristus yang telah mati dan bangkit bagi semua orang." 46

Pemikiran Eka Darmaputera mengenai gerakan pluralisme agama berfokus pada teologi kontekstualisasi. Ia berpendapat bahwa teologi kontekstualisasi merupakan teologi itu sendiri yang berarti teologi hanya dapat disebut sebagai teologi apabila ia benar-benar kontekstual dengan zaman. Hal ini diungkapkan Darmaputera demikian, "Secara lebih sederhana dapat dikatakan bahwa teologi adalah upaya untuk merumuskan penghayatan iman Kristen pada konteks ruang dan waktu yang tertentu." ${ }^{47}$ Pernyataan ini memberikan sumbangsih besar bagi para teo$\log$ Indonesia lain untuk mengembangkan gagasan pluralisme.

Th. Sumartana yang pernah terlibat di dalam Tim Balitbang (Badan Penelitian dan Pengembangan Persekutuan Gereja-gereja di Indonesia) PGI, pada akhirnya muncul sebagai pemikir pluralisme agama yang cukup mengagetkan dalam perkembangan pluralisme agama di Indonesia. Ia memopulerkan konsep "Theologia Religionum" di bumi Pancasila. Istilah tersebut dapat dimengerti sebagai evaluasi dan interpretasi tentang gejala agama-agama bukan Kristen di dunia dari perspektif iman Kristen. Menurutnya, "teologi agama-agama haruslah merupakan bagian dari upaya agama-agama untuk merelevansikan seluruh jawaban-jawaban teologisnya terhadap seluruh persoalan

46"Religious Tolerance and the Christian Faith" (disertasi, Princeton Theological Seminary, 1960), 174.

47"Menuju Teologi Kontekstual," dalam Konteks Berteologi di Indonesia, ed. Eka Darmaputera (Jakarta: Gunung Mulia, 1988), 9. masyarakat."48 Dengan kata lain, teologi agama-agama adalah "upaya refleksi teologis untuk menempatkan pluralisme sebagai pusat perhatian dan pusat persoalan." $49 \mathrm{Hal}$ ini membuat teologi agama-agama terbuka untuk semua agama sehingga semua agama dapat membuat teologi agamanya sendiri yang terbuka dan positif.

Jika semua agama dapat membuat teologi agamanya sendiri maka dialog antaragama dapat dilakukan. Harapannya adalah dapat memperkaya kekristenan dan demikian pula sebaliknya. Sumartana menulis, "Dialog antaragama menerima hak untuk berbeda dan memberikan keabsahan dari pengalaman religius yang berbeda sebagai jalan menuju kepada Kerajaan Allah." ${ }^{50}$ Dialog demikian akan menuntut pengakuan yang tulus dan rasa saling menghormati karena tidak ada agama yang dominan dan semua agama samasama unik. Konsekuensinya adalah keunikan Kristus tidak dapat dipertahankan lagi karena identik dengan kekuasaan imperialisme serta tidak terbuka kepada agama-agama lain.

Th. Sumartana juga berpendapat bahwa pluralisme agama bersangkut paut dengan dunia mistik. Dalam dunia ini, sesuatu yang menjadi pengalaman utama adalah kesenangan berada di hadapan hadirat Tuhan. Menurut Sumartana, "Kebenaran agama tidak akan habis dicerna oleh akal, tidak akan sepenuhnya bisa digapai oleh upacara ritual; kaum mistikus cenderung ingin mengalami kehadiran Tuhan dalam zikir, tarian, dan meditasi." ${ }^{51}$ Berdasarkan pengalaman tersebut,

\footnotetext{
48"Pemikiran Kristen mengenai Pluralisme menuju Upaya Merumuskan Teologi Agama-agama di Indonesia," dalam Pluralisme dan Demokrasi: Kumpulan Karangan Seminar Agama-agama XII/1992, ed. Fridolin Ukur dan Retnowinarti (Jakarta: Balitbang PGI, 1995), 39.

${ }^{49}$ Th. Sumartana, "Theologia Religionum," dalam Meretas Jalan Teologi Agama-agama di Indonesia: Theologia Religionum, ed. Tim Balitbang PGI (Jakarta: Gunung Mulia, 1999), 21-26.

50“Beberapa Pemikiran tentang Panggilan dan Tanggung Jawab Gereja terhadap Lingkungan Masyarakatnya," Bina Darma 34, no. 9 (1991): 83.

51"Beberapa Tema Dialog Antar-Agama Kontemporer," dalam Agama dalam Dialog: Pencerahan, Pen-
} 
dunia beserta isinya menjadi nisbi. Konsekuensinya, perbedaan antaragama menjadi cair dan kesatuan dengan Tuhan mengatasi segala perbedaan.

Bagi Ioanes Rakhmat, pluralisme agama bersangkut paut dengan ide pengalaman universal setiap orang dengan realitas. Ia menegaskan, "setiap pihak dalam relasi antar-umat beragama perlu mengalami perjumpaan yang akrab dan intim dengan Realitas lain yang transenden, Realitas spiritual, yang menjadi pusat batiniah yang dari dalamnya muncul motivasi untuk hidup dalam kebajikan dan cinta kepada sesama manusia." 52 Bagi Rakhmat, setiap agama memiliki kesempatan yang sama untuk berelasi dengan Tuhan sesuai dengan keyakinan dan tata cara agamanya masing-masing. Dengan begitu, diharapkan relasi yang akrab itu berdampak etis kepada perilaku setiap pemeluk agama dalam kesehariannya.

Berkenaan dengan pluralisme agama, John A. Titaley mengungkapkan bahwa antara Yang Mutlak dan manusia terjalin suatu relasi. Apakah dan bagaimanakah respons manusia atas relasi tersebut? Relasi itu direspons oleh manusia dengan keterbatasan simbol-simbol budayanya seperti bahasa. Bahasa dan simbol budaya yang dipakai oleh manusia tidak mencerminkan kesempurnaan simbol dan bahasa Yang Mutlak. Konsekuensinya, hal ini menunjukkan bahwa terdapat reduksi dalam upaya manusia untuk memahami Yang Mutlak itu. Itulah keterbatasan manusia di hadapan Yang Mutlak itu. Dalam keadaan seperti itu, maka tidak seorang manusia pun yang dapat mengklaim bahwa dia dapat

damaian, dan Masa Depan: Punjung Tulis 60 tahun Prof. Dr. Olaf Herbert Schumann, ed. Panitia Penerbitan Buku Kenangan Prof. Dr. Olaf Herbert Schumann, Balitbang PGI (Jakarta: Gunung Mulia, 1999), 112-113.

\footnotetext{
52"Bangunan Agama dan Toleransi," dalam Agama dalam Dialog: Pencerahan, Pendamaian, dan Masa Depan: Punjung Tulis 60 tahun Prof. Dr. Olaf Herbert Schumann, ed. Panitia Penerbitan Buku Kenangan Prof. Dr. Olaf Herbert Schumann, Balitbang PGI (Jakarta: Gunung Mulia, 1999), 84.
}

memahami kehendak Yang Mutlak itu secara sempurna. ${ }^{53}$

Menurut Titaley, kebenaran di dalam kekristenan pun mengalami reduksi sama seperti kebenaran di dalam agama-agama lain. Hal ini dapat terjadi karena keterbatasan simbol-simbol budaya manusia (bahasa) dalam memahami kehendak Tuhan. Implikasi logisnya adalah setiap penganut agama apa pun termasuk Kristen tidak dapat menangkap dan memahami kebenaran yang utuh. Kekristenan memiliki kontinuitas dengan iman agama-agama lain sehingga ia tidak lebih benar daripada mereka semua.

Berdasarkan pemikiran pluralis Kristen di atas maka dapat disimpulkan bahwa W.B. Sidjabat tergolong sebagai tokoh yang banyak berbicara dan terlibat di dalam toleransi dan dialog agama-agama di Indonesia di mana kelak pemikirannya dikembangkan untuk menjadi pandangan pluralisme. Eka Darmaputera sebagai seorang yang bergumul dengan teologi kontekstualisasi di mana pemikirannya juga menjadi dasar untuk pengembangan gagasan pluralisme. Th. Sumartana, Ioanes Rakhmat, dan Titaley justru mengambil posisi pluralis yang berpendapat bahwa Alkitab bukan satu-satunya firman Allah. Selain itu, keselamatan bukan satu-satunya di dalam Yesus Kristus melainkan keselamatan ada di dalam ajaran agama masing-masing. Disamping itu, toleransi antarumat beragama sangat diperlukan untuk menjaga kedamaian di kawasan Indonesia.

\section{Epistemologi Pemikiran Kristen Pluralis tentang Pluralisme Agama di Indonesia}

Pada umumnya gagasan-gagasan para pemikir Kristen pluralis di Indonesia di atas tidak jauh berbeda dengan semua gagasan kaum pluralis dunia seperti John Hick, Paul Knitter, Raimundo Panikkar. Hal ini disebabkan pendidikan lanjut yang mereka tempuh berlokasi di negara-negara yang diwarnai dengan pluralisme agama sebagai cara berteologi.

\footnotetext{
${ }^{53}$ Religiusitas di Alinea Tiga: Pluralisme, Nasionalisme dan Transformasi Agama-agama (Salatiga: Satya Wacana University Press, 2013), 170-71.
} 
Epistemologi pemikiran Kristen pluralis tersebut meliputi beberapa hal. Pertama, konteks wilayah Indonesia: Latar belakang agama-agama pendatang yang sama sekali berbeda konteks bumi Indonesia. Perbedaan yang dimaksud mencakup perihal geografis, iklim, sosial, politik, dan budaya. Implikasinya, lahir sebuah filosofi religius yang berbeda dari agama-agama "asal" di Indonesia. Bambang R. Utomo menjelaskan hal ini dengan gamblang, "Agama agama [pendatang] terbiasa membagi dunia menjadi dua, yakni dunia kafir, dunia yang belum percaya. Agamaagama yang belum banyak mempunyai pengalaman hidup bersama dengan umat beragama lain secara heterogen." ${ }^{54}$ Agama-agama tersebut lambat laun menggeser dan menggantikan agama-agama sebelumnya. Hal ini mengakibatkan dikotomi religius tersebut diwariskan dari satu generasi ke generasi yang lain. Ujung-ujungnya, dikuatirkan toleransi beragama tidak dapat dilakukan dengan semestinya di Indonesia yang berdasar pada Pancasila dan memiliki semboyan "Bhinneka Tunggal Ika.”

Kedua, empirisme: Pandangan bahwa semua agama sama didasari dengan fakta fenomena agama-agama dan akhir dari tujuan agamaagama. ${ }^{55}$ Dari sisi positif, fenomena semua agama sama-sama mengajarkan kebajikan bagi pemeluknya, yaitu hidup baik, bijaksana, dan kudus. Secara historis-kultural, masing-masing agama dibentuk oleh pengaruh-pengaruh konteks budaya hirarki-dogmatis dan hasil rekonstruksi filosofis. Termasuk klaim agama paling unggul adalah produk dari interaksi kreatif antara pengaruh-pengaruh budaya yang hierarkis.

Ketiga, relativisme atau subjektivisme: sebuah paham yang menganggap bahwa semua agama sama, semua agama adalah benar dan semua agama memiliki keprihatinan yang

${ }^{54}$ Hidup Bersama di Bumi Pancasila: Sebuah Tinjauan Hubungan Islam dan Kristen di Indonesia (Malang: Pusat Studi Agama dan Kebudayaan, 1993), 258.

\footnotetext{
${ }^{55}$ Sudianto Manullang, "Konflik Agama dan Pluralisme Agama di Indonesia, “ Te Deum 4, no. 1 (Juli-Desember 2014), 112.
}

sama. ${ }^{56}$ Kebenaran yang ada di dalam setiap agama di Indonesia diyakini oleh kaum pluralis menunjuk kepada kebenaran yang sama di mana masing-masing agama memiliki "kebenaran" yang bersifat parsial dan komplementari. Gordon D. Kaufman menegaskan hal senada, "None of us-Christian or non-Christian-possesses absolute or final truth, truth adequate to orient humankind in face of the enormous problems we confront in today's world. ${ }^{57}$ Absolutisme kebenaran agama apa pun tidak dapat diberlakukan dan dipertahankan lagi.

\section{Aplikasi Apologetika Prasuposisional}

Triperspektivalisme John M. Frame terhadap Pemikiran Kristen Pluralis tentang Pluralisme Agama di Indonesia

Di bagian ini, APT akan diaplikasikan untuk menyoal pemikiran kaum pluralis Kristen tentang pluralisme agama di Indonesia. Hal ini akan dilakukan berdasarkan kemampuan triperspektivalisme untuk menghadapi epistemologi pemikiran Kristen pluralis, yaitu dengan menunjukkan sebagai perspektif normatif, membela sebagai perspektif eksistensial, dan menyingkapkan sebagai perspektif situasional. Ketiga perspektif ini akan muncul di dalam tiga strategi apologetika, yaitu apologetika konstruktif (normatif), ofensif (situasional), dan defensif (eksistensial). ${ }^{58}$

\section{Apologetika Konstruktif (Normatif)}

Apologetika konstruktif adalah sebuah strategi untuk menunjukkan sebuah dasar rasional bagi iman Kristen. Dengan kata lain, sebuah usaha untuk menunjukkan bahwa

\footnotetext{
${ }^{56}$ Kebenaran adalah "Questions about meaning and truth will be related to the way we actually live. ... Doing the truth is one way of showing what the truth is, what the world is really like" (Kevin J. Vanhoozer, First Theology: God, Scripture and Hermeneutics [Downers Grove: InterVarsity Academic, 2002], 363-364).

57" Religious Diversity, Historical Consciousness, and Christian Theology" dalam The Myth of Christian Uniqueness, ed. John Hick dan Paul F. Knitter (London: SCM, 1988), 13.

${ }^{58}$ John M. Frame, Apologetics: A Justification of Christian Belief, ed. Joseph E. Torres, ed. ke-2 (Phillipsburg: P\&R, 2015) 3 .
} 
kekristenan itu benar di mata kaum pluralis. Segala bukti dan argumentasi dapat dipakai dalam usaha tersebut dengan memprasuposisikan Kitab Suci adalah firman Allah yang menjadi sumber, standar, dan metode bagi seorang percaya dalam mempelajari kebenaran. Di luar hal tersebut adalah pemberhalaan. William C. Davis berpendapat senada, "The Bible never suggests that we should attempt to defend the faith from a position of neutrality." ${ }^{59} \mathrm{Hal}$ ini berarti tidak ada netralitas di dalam berapologetika.

\section{Perspektif Normatif}

Perspektif normatif dari apologetika konstruktif adalah seorang apologet Kristen menjelaskan kepada kaum pluralis bahwa setiap manusia memiliki pengetahuan akan Allah. Pengetahuan ini diperoleh dari penyataan Allah baik melalui Kitab Suci maupun dunia dan manusia. Kitab Suci menyatakan bahwa alam diciptakan oleh Allah untuk menyatakan diri-Nya baik bagi orang Kristen maupun non-Kristen. Lebih lanjut, Frame menegaskan, "Creation and providence do show that God exists, and they also reveal his character, his righteous standards for human life, and his holy wrath against human sin." 60 Allah menciptakan alam semesta supaya orang-orang menyadari bahwa Allah itu ada tetapi bukan melaluinya, mereka memperoleh keselamatan kekal. Kemudian Kitab Suci memberitahu identitas Allah itu, yaitu sang Pencipta alam semesta yang dikenal melalui Yesus Kristus dan Kitab Suci.

\section{Perspektif Situasional}

Di dalam perspektif situasional, seorang apologet akan menunjukkan kepada kaum Kristen pluralis tentang fakta-fakta yang ada di dalam dunia di mana mendukung akan keberadaan Allah yang berpribadi dan memiliki atribut

\footnotetext{
${ }^{59}$ William C. Davis, "Frame in the Context of Recent Apologetics," dalam Speaking the Truth in Love: The Theology of John M. Frame, ed. John J. Hughes (Phillipsburg: P\&R, 2009), 493.

${ }^{60}$ John M. Frame, Perspective on the Word of God: An Introduction to Christian Ethics (Phillipsburg: P\&R, 1990), 21.
}

kontrol, otoritas, dan kehadiran. Fakta-fakta tersebut diprasuposisikan dari konsep ketuhanan dan dipakai untuk memuliakan Allah. Ia dapat menjelaskan terlebih dahulu bahwa Allah dinyatakan secara jelas melalui alam semesta melalui argumen kosmologis, teleologis, keberadaan yang sempurna. ${ }^{61}$ Argumen-argumen di atas memprasuposisikan Allah yang dinyatakan di dalam Kitab Suci. Jika tidak demikian, premis-premis tersebut akan menghasilkan kesimpulan yang berbeda dengan yang dimaksudkan Kitab Suci.

\section{Perspektif Eksistensial}

Perspektif eksistensial dari apologetika konstruktif akan menunjukkan bahwa seorang apologet dapat menjelaskan dan membuktikan bahwa kekristenan itu rasional, bukan berdasarkan pada kemampuannya sendiri. Sebaliknya, semua itu dilakukan karena Kitab Suci menjadi komitmen tertinggi bagi dirinya. Hal itu akan ditunjukkan dengan sikap yang rendah hati dan memegang hal itu secara konsisten dan penuh ketaatan di dalam kehidupannya. Implikasinya, ia akan mampu untuk menginterpretasi Kitab Suci dengan benar dan tepat. Selain itu, ia dapat menjelaskan apa yang ia imani di dalam Kristus Yesus kepada kaum pluralis dengan lembah lembut dan hormat.

\section{Apologetika Defensif (Eksistensial)}

Ketika kaum pluralis telah mendengar segala penjelasan dari apologet Kristen mengenai Allah yang dinyatakan di dalam Kitab Suci, Yesus Kristus, alam semesta, dan manusia disertai pula dengan argumen-argumen yang mendukungnya, maka mereka akan memberikan respons. Respons yang dimaksud adalah inisiatif untuk mempertanyakan kembali kebenaran kekristenan dari prasuposisi pluralis. Seorang apologet harus siap sedia untuk menjawab setiap keberatan yang diajukan oleh mereka. Hal ini akan dilakukan di dalam apologetika defensif yang berfokus pada perspektif eksistensial di mana juga melibatkan perspektif normatif dan situasional.

\footnotetext{
${ }^{61}$ Lihat Frame, Apologetics: A Justification, 116.
} 


\section{Perspektif Normatif}

Perspektif normatif dari apologetika defensif menekankan sejauh mana seorang apologet memahami Kitab Suci dan terampil untuk menggunakannya demi mempertahankan kebenaran iman Kristen. Berdasarkan epistemologinya, kaum pluralis akan mempertanyakan kepada kaum Injili mengenai konsep ketuhanan kaum Injili, yaitu dasar keyakinan kepada Tuhan yang diwahyukan dalam Kitab Suci adalah Tuhan yang benar dan tidak sama dengan allah yang dinyatakan di dalam agama-agama lain. Untuk menanggapi pertanyaan ini, kaum Injili perlu menjelaskan kepada kaum pluralis tentang sumber otoritasnya yang tertinggi, yaitu Kitab Suci. Kitab Suci menyatakan bahwa Allah yang dinyatakan di dalam Kitab Suci adalah Tuhan yang benar dan sejati. Ia tidak dapat dibandingkan dengan ilah-ilah lain di dalam agama-agama yang lain. Demikian polanya adalah Kitab Suci menyatakan rasionalitas Allah kemudian hal itu diterima dengan iman oleh manusia dan itu menjadi pola berpikir dari manusia tersebut.

Konkretnya, kaum Injili dapat menjelaskan kepada kaum pluralis tentang sejumlah epistemologi tradisional yang cenderung dipakai oleh umat manusia, yaitu rasionalisme, empirisme, dan subjektifisme. ${ }^{62}$ Pertama, rasionalisme adalah pandangan yang menyatakan bahwa pengetahuan manusia mengasumsikan adanya prinsip-prinsip tertentu yang dipahami terlepas dari pengalaman pancaindra dan prinsip-prinsip itulah yang mengatur pengalaman pancaindranya. Kedua, empirisme adalah pandangan yang menyatakan bahwa pengetahuan itu didasarkan pada pengalaman pancaindra. Ketiga, subjektivisme adalah pandangan yang menyatakan bahwa tidak ada kebenaran "objektif," yang ada adalah kebenaran "bagi" subjek yang dibuktikan dengan kriteria internal subjek itu sendiri.

\footnotetext{
${ }^{62}$ Lihat penjelasan detail di Frame, The Doctrine of the Knowledge of God, 109-122.
}

\section{Perspektif Situasional}

Dalam perspektif ini, kaum Injili dapat mempergunakan bukti-bukti di luar Alkitab untuk membela Kitab Suci terhadap keberatan dari kaum pluralis dengan catatan buktibukti tersebut diinterpretasi secara alkitabiah. Geivett dan Phillips menyadari bahwa di dalam proses dialog jika seseorang tidak menerima dan mengalami kebenaran firman Tuhan maka pemaparan bukti-bukti diperlukan. ${ }^{63}$ Gagasan dari kaum pluralis mengenai semua agama menyembah Tuhan yang sama (the Real atau Ultimate Reality) tidak masuk akal. Hal ini disebabkan kaum pluralis-dan kebanyakan orang di dunia-menyimpulkannya dari segelintir agama besar di dunia tanpa memperhitungkan sejumlah keyakinan lain yang notabene minoritas.

\section{Perspektif Eksistensial}

Dalam perspektif ini, kaum Injili berapologetika terhadap kaum pluralis untuk meyakinkan mereka akan kebenaran Kitab Suci. Hal ini dilakukan dengan berusaha untuk mendengar dan memahami dengan penuh kasih kebutuhan dari kaum pluralis. Kaum Injili perlu menyadari bahwa ketika mereka memberikan dorongan kepada kaum pluralis untuk mengakui imannya di hadapan Allah yang dinyatakan di dalam Kitab Suci, ada kemungkinan mereka menolak. Hal ini disebabkan mereka mengetahui kebenaran, tetapi sedang menekan, membengkokkan, bahkan memutarbalikkan kebenaran itu. Sebab itu, dapat dipahami bahwa akar dari penolakan kaum pluralis adalah masalah hati yang kemudian memengaruhi intelektual mereka (the noetic effects of $\sin$ ).

\section{Apologetika Ofensif (Situasional)}

Ketika kaum Injili berapologetika dengan kaum pluralis, mereka bukan hanya memaparkan dan membela kekristenan tetapi juga menyingkapkan "kebodohan" dari kaum

${ }^{63}$ Lihat "A Particularist View: An Evidentialist Approach," dalam Four Views on Salvation in a Pluralistic World, ed. Dennis L. Okholm dan Timothy R. Phillips (Grand Rapids: Zondervan, 1996), 215. 
pluralis. Dalam strategi ini, kaum Injili dipanggil untuk menjadi orang-orang yang membukakan pemikiran dan hati-tentu saja dalam pertolongan Roh Kudus-dari kaum pluralis dengan penuh kasih dan lemah lembut.

\section{Perspektif Normatif}

Dalam perspektif ini, APT berfokus kepada situasi dan kondisi dari kaum pluralis tetapi tetap melibatkan perspektif normatif dan eksistensial. Kaum Injili akan mendengar dengan saksama dan menyesuaikan pendekatannya dengan kebutuhan spesifik dari kaum pluralis agama. Seorang apologet Kristen mengalihkan perhatiannya dari menghibur orang percaya kepada berhadapan dengan dunia yang belum diregenerasikan (percaya kepada Yesus), maka penekanan APT atas konteks dan mendengar budaya menjadi krusial. Konteks Indonesia sangat heterogen di dalam segala hal, termasuk agama. Kebenaran-kebenaran Kristen bersifat rasional ketika diukur terhadap standar rasionalitas Allah. Namun, standar rasionalitas demikian yang dibantah oleh kaum pluralis. Kaum pluralis menggantikan kebenaran dengan dusta, menggeser Allah dari tempat yang seharusnya dan menggantikan diri-Nya dengan ilahilah yang lain. Tindakan ini merefleksikan struktur pemikiran otonomis yang disebut dialektika rasionalis-irasionalis. Kaum pluralis mencoba untuk menjadikan epistemologinya sendiri (empirisme, subjektivisme, dan rasionalisme) sebagai kriteria kebenaran dan menolak wahyu Allah. Pola pikir ini yang disebut rasionalisme. Konsekuensinya, mereka akan jatuh pada ateisme. Tidak ada pilihan yang lain atau daerah abu-abu. Jika kaum pluralis tidak menyembah Allah yang dinyatakan di dalam Kitab Suci maka mereka menyangkal Allah (teoritis) dan hidup seolah-olah Allah tidak ada (praktis). ${ }^{64}$ Di saat yang sama, kaum pluralis juga menyangkal adanya kebenaran yang mutlak dan final di dalam Yesus Kristus dan Kitab Suci. Hal ini yang disebut irasionalisme. Pola pikir ini akan berakhir pada penyembahan berhala (idolatry) di mana kaum pluralis menjadikan

${ }^{64}$ Lihat Frame, Apologetics: A Justification, 198. dirinya dan kebenarannya sebagai kebenaran mutlak. Jadi, dialektika ini bersumber dari ketidakpercayaan kaum pluralis.

\section{Perspektif Situasional}

Munculnya pluralisme telah membuat konteks apologetika menjadi sangat jelas. Dalam APT, perspektif situasional penting seperti yang telah ditekankan oleh Petrus dan Paulus di dalam Kisah Para Rasul 10; 11; 17:1634. Perlu diketahui bahwa Perjanjian Baru ditulis di tengah pluralitas budaya. Daripada membela iman dengan pemikiran objektif, pemikiran rasional, para apologet abad pertama akan menempatkan kesetiaan kepada ketuhanan Kristus pada awal dari argumen mereka dan mendorong orang tidak percaya untuk bertobat. Mereka mengenali bahwa permasalahan yang sebenarnya bukan berkenaan dengan perihal intelektual semata melainkan kebutaan dan pemberontakan rohani.

\section{Perspektif Eksistensial}

Dalam perspektif ini, kaum Injili berusaha untuk mengenal para pemikir Kristen pluralis sebagai individu-individu. Hal ini dilakukan dengan dialog yang berlangsung dua arah dan lebih banyak saling mendengarkan. Hal ini merupakan wujud dari kasih Allah yang tidak bersyarat. Lalu kaum Injili berbicara dengan cara yang dapat dimengerti oleh masingmasing pihak sesuai dengan permasalahan yang dihadapi (case by case). Mengapa kaum injil perlu berdialog dengan agama-agama lain? Jawabannya sederhana, yaitu sebab Yesus sudah terlebih dahulu melakukannya. Jadi, tidak ada alasan bagi kaum Injili untuk tidak berdialog dengan agama-agama lain.

Titik kontak di dalam dialog ini bukan berada pada kriteria kebenaran netral yang tidak mengasumsikan kepercayaan maupun ketidakpercayaan melainkan pada beberapa fakta atau norma yang yang diketahui baik oleh kaum Injili maupun pluralis. Konkretnya, pengetahuan tentang Allah dari penyataan Allah. Hal ini ditekankan oleh Frame, yaitu "Our appeal is not to those criteria, but to that knowledge of God which the unbeliever 
has "deep down," as Van Til liked to say. The point-of-contact issue, therefore, is a spiritual one, one by which we examine our motives, not one by which we can quickly assess the intentions of our fellow apologists." ${ }^{65}$ Titik kontak ini tidak dimulai dari prasuposisi kaum pluralis yang menunjukkan otonomi dan netralitas melainkan dari pengetahuan yang diberikan oleh Tuhan kepada mereka di mana telah ditekan dan diputarbalikkan.

Dari penguraian di atas, APT Frame dapat digunakan untuk menjawab tantangan pemikiran Kristen pluralis tentang pluralisme agama di Indonesia. Hal ini dapat dibuktikan dari kemampuan APT untuk tetap setia kepada otoritas dan keunikan Kitab Suci sambil menjelaskan bahwa kekristenan itu rasional, mampu membela iman Kristen secara kontekstual dan mampu menjawab keberatan-keberatan yang diajukan oleh para pemikir Kristen pluralis terhadap kekristenan Injili, dan menyingkapkan pemikiran dan hati para pemikir Kristen pluralis tentang kerapuhan epistemologi mereka yang pada akhirnya membawa mereka kepada ketidakjelasan dan kesalahan. Walaupun demikian, APT dilakukan dengan bersandar kepada pertolongan Tuhan dan argumen-argumen yang

${ }^{65}$ Frame, Apologetics to the Glory of God, 85. Lihat juga K. Scott Oliphint, The Battle Belongs to the Lord: The Power of Scripture for Defending Our Faith (Phillipsburg: P\&R, 2003), 172. Oliphint menekankan, "Our 'point of connection,' or of persuasion, with the unbeliever is the truth that God has given to him." digunakan ini hanya merupakan alat yang dapat dipakai oleh Allah untuk membawa mereka kepada perubahan hati dan pikiran.

\section{Kesimpulan}

Pluralisme adalah sebuah pandangan yang menyatakan bahwa tidak ada yang superior atau inferior karena semua sama. Hal ini berlaku di dalam segala aspek kehidupan manusia termasuk agama. Konsekuensinya, tidak ada satu agama pun yang berhak untuk mengklaim dirinya sebagai keyakinan yang paling benar di antara agama-agama lain di dunia termasuk di Indonesia. Para pemikir Kristen pluralis di Indonesia juga memiliki pandangan demikian. Karena itu, hal ini menjadi tantangan bagi kaum Kristen Injili untuk berapologetika demi menjelaskan dan mempertahankan keunikan iman Kristen. Apologetika prasuposisional triperspektivalisme John M. Frame mampu menjelaskan, membela, dan menyingkapkan kebenaran Kitab Suci kepada kaum Kristen pluralis secara kontekstual tanpa mengkompromikan-Nya. Hal ini dapat terjadi karena setiap argumentasi apologetika memprasuposisikan kebenaran firman Allah. 


\section{Daftar Kepustakaan}

Boa, Kenneth D. dan Robert M. Bowman Jr. Faith Has Its Reasons: Integrative Approaches to Defending the Christian Faith. Ed. ke-2. Colorado Springs: Paternoster, 2006.

Clendenin, Daniel B. Many Gods, Many Lords: Christianity Encounters World Religions. Grand Rapids: Baker, 1995.

Darmaputera, Eka. “Menuju Teologi Kontekstual.” Dalam Konteks Berteologi di Indonesia, diedit oleh Eka Darmaputera, 1-15. Jakarta: Gunung Mulia, 1988.

Davis, William C. "Frame in the Context of Recent Apologetics." Dalam Speaking the Truth in Love: The Theology of John M. Frame, diedit oleh John J. Hughes, 489-524. Phillipsburg: P\&R, 2009.

Edgar, William dan K. Scott Oliphint, ed. Christian Apologetics Past and Present: A Primary Source Reader: From 1500-. Wheaton: Crossway, 2011.

Ferdinandus, Williem. "Trinity and Religious Pluralism: Peran Doktrin Trinitas dalam Pluralitas Agama.” Amanat Agung 9, no. 2 (Desember 2013): 200-221.

Frame, John M. “Introduksi pada Iman Reformed.” Veritas 8, no. 2 (Oktober 2007): 169-189.

. "Logic." Dalam Dictionary for Theological Interpretation of the Bible, diedit oleh Kevin J. Vanhoozer, 462-464. Grand Rapids: Baker Academic, 2005.

. "Presuppositional Apologetics." Dalam Five Views on Apologetics, diedit oleh Steven B. Cowan, 208-231. Grand Rapids: Zondervan, 2000.

. "Presuppositional Apologetics." Dalam New Dictionary of Christian Apologetics, diedit oleh W.C. Campbell-Jack, Gavin McGrath, dan C. Stephen Evans, 576-579. Leicester: InterVarsity Academic, 2006.

. "The Spirit and the Scriptures." Dalam Hermeneutics, Authority, and Canon, diedit oleh D.A. Carson dan John D. Woodbridge, 213-235. Grand Rapids: Zondervan, 1986.

. Apologetics to the Glory of God: An Introduction. Phillipsburg: P\&R, 1994.

. Apologetics: A Justification of Christian Belief. Ed. ke-2. Diedit oleh Joseph E. Torres. Phillipsburg: P\&R, 2015.

. Cornelius Van Til: An Analysis of His Thought. Phillipsburg: P\&R, 1995.

1990.

.Perspectives on the Word of God: An Introduction of Christian Ethics. Phillipsburg: P\&R,

. The Doctrine of God. Phillipsburg: P\&R, 2002.

. The Doctrine of the Christian Life. Phillipsburg: P\&R, 2008.

. The Doctrine of the Knowledge of God. Phillipsburg: P\&R, 1987.

. The Doctrine of the Word of God. Phillipsburg: P\&R, 2010.

Givett, dan Timothy R. Phillips. "A Particularist View: An Evidentialist Approach.” Dalam Four Views on Salvation in a Pluralistic World, diedit oleh Dennis L. Okholm dan Timothy R. Phillips. Grand Rapids: Zondervan, 1996. 
GP, Harianto. "Gagasan Pluralisme Agama: Tinjauan Sejarah dari Indonesia sampai Kini dan Tawaran Dialog 'Kebenaran Agaphe.”' Pelita Zaman 16, no. 1 (Mei 2001): 31-57.

Kärkkäinen, Veli-Matti. Trinity and Religious Pluralism: The Doctrine of the Trinity in Christian Theology of Religions. Aldershot: Ashgate, 2008.

Kaufman, Gordon D. "Religious Diversity, Historical Consciousness, and Christian Theology." Dalam The Myth of Christian Uniqueness, diedit oleh John Hick dan Paul F. Knitter, 1-16. London: SCM, 1988.

Lukito, Daniel L. "Eksklusivisme, Inklusivisme, Pluralisme, dan Dialog Antar-Agama." Veritas 13, no. 2 (Oktober 2012): 251-279.

Manullang, Sudianto. "Konflik Agama dan Pluralisme Agama di Indonesia." Te Deum 4, no. 1 (Juli-Desember 2014): 111-129.

Oliphint, K. Scott. The Battle Belongs to the Lord: The Power of Scripture for Defending Our Faith. Phillipsburg: P\&R, 2003.

Rakhmat, Ioanes. Membedah Soteriologi Salib: Sebuah Pergulatan Orang Dalam. Ed ke-2. Jakarta: Borobudur, 2010.

."Bangunan Agama dan Toleransi." Dalam Agama dalam Dialog: Pencerahan, Pendamaian, dan Masa Depan: Punjung Tulis 60 tahun Prof. Dr. Olaf Herbert Schumann, diedit oleh Panitia Penerbitan Buku Kenangan Prof. Dr. Olaf Herbert Schumann, Balitbang PGI, 78-89. Jakarta: Gunung Mulia, 1999.

. "The Freethinker Blog: Album buku-buku saya My books album." The Freethinker Blog. August 6, 2012. Diakses 2 Mei 2017. http://ioanesrakhmat.blogspot.co.id/2012/08/ album-buku-buku-saya.html.

Sidjabat, W.B. "Religious Tolerance and the Christian Faith." Disertasi, Princeton Theological Seminary, 1960.

. Religious Tolerance and the Christian Faith. Jakarta: Gunung Mulia, 1965.

Sumartana, Th. "Beberapa Pemikiran tentang Panggilan dan Tanggung Jawab Gereja terhadap Lingkungan Masyarakatnya, “ Bina Darma 34, no. 9 (1991): 75-90.

. "Beberapa Tema Dialog Antar-Agama Kontemporer." Dalam Agama dalam Dialog: Pencerahan, Pendamaian, dan Masa Depan: Punjung Tulis 60 tahun Prof. Dr. Olaf Herbert Schumann, diedit oleh Panitia Penerbitan Buku Kenangan Prof. Dr. Olaf Herbert Schumann, Balitbang PGI, 110-118. Jakarta: Gunung Mulia, 1999.

. "Pemikiran Kristen mengenai Pluralisme menuju Upaya Merumuskan Teologi Agama-agama di Indonesia." Dalam Pluralisme dan Demokrasi: Kumpulan Karangan Seminar Agama-agama XII/1992, diedit oleh Fridolin Ukur dan Retnowinarti, 32-45. Jakarta: Balitbang PGI, 1995.

. "Theologia Religionum.” Dalam Meretas Jalan Teologi Agama-agama di Indonesia: Theologia Religionum, diedit oleh Tim Balitbang PGI, 21-26. Jakarta: Gunung Mulia, 1999.

Titaley, John A. Religiositas di Alenia Tiga: Pluralisme, Nasionalisme dan Transformasi Agamaagama. Salatiga: Satya Wacana University Press, 2013. 
Utomo, Bambang R. Hidup Bersama di Bumi Pancasila: Sebuah Tinjauan Hubungan Islam dan Kristen di Indonesia. Malang: Pusat Studi Agama dan Kebudayaan, 1993.

Vanhoozer, Kevin J. First Theology: God, Scripture and Hermeneutics. Downers Grove: InterVarsity Academic, 2002.

Wim, Chandra. "The Cronicles of Evangelicalism: Sebuah Pengantar Historis terhadap Gerakan Evangelikal.” Veritas 12, no. 2 (Oktober 2011): 185-207. 